\title{
How Can a Destination Better Manage Its Offering to Visitors? Observing Visitor Experiences via Online Reviews
}

\author{
Hany Kim ${ }^{1}\left(\mathbb{D}\right.$, Hyo Jae Joun ${ }^{2}$, Yeongbae Choe ${ }^{3, *}$ and Ashley Schroeder ${ }^{4}$ \\ 1 Department of Tourism and Convention, Pusan National University, Busan 46241, Korea \\ 2 Korea Culture \& Tourism Institute, Seoul 07511, Korea \\ 3 Department of Integrated Resort and Tourism Management, University of Macau, Macao 999078, China \\ 4 Department of Recreation, Park, and Tourism Management, Pennsylvania State University, \\ State College, PA 16802, USA \\ * Correspondence: ychoe@um.edu.mo
}

Received: 14 July 2019; Accepted: 21 August 2019; Published: 27 August 2019

\begin{abstract}
Destinations are competing every day to attract more tourists and increase tourism receipts. In order to maintain tourists' interests in the destination and expect sustainable income from tourism, understanding tourists' perceptions of the destination is a critical task for destination managers. Tourists' continuous visitation can be ensured when destinations are perceived to be positive and attractive. Therefore, this study examines destination attributes that are fundamental elements of the destination and tourists' experiences. More specifically, this study investigates the destination attributes that are perceived to be positive by tourists using online reviews. Online reviews were analyzed with content analysis techniques and the quantified content was statically compared with the star rating provided by tourists. In addition, the influence of destination attributes on other conation dimensions-attitude and behavior-was analyzed. Destination attributes that have an influence on the star rating showed similar results to the attitude. However, behavior dimensions only had a significant influence for tour guides' quality of the destination.
\end{abstract}

Keywords: destination offering; destination attribute; visitor experience; online review; micro-scale destination; local attraction; UCG; economic sustainability

\section{Introduction}

Destinations, regardless of their size, have focused on developing tourism for the economic benefits that tourism brings to the destination [1]. This phenomenon led to intense competition amongst destinations for building tourism infrastructure to both attract and support more tourists. This short-sighted perspective to tourism development, which emphasized the economic benefits of tourism, has resulted in unsustainable consequences that ultimately damage the environment and host community of destinations across the globe [2,3]. To address the negative impacts of tourism, in more recent times, researchers and practitioners have increasingly shown great interest in sustainable tourism development [4]. Sustainable tourism development is built around a triple bottom line framework, which includes the economic, social, and environmental dimensions [5,6], to ensure that locals have long-term sustainable benefits from tourism while still providing a satisfactory experience to tourists $[7,8]$. A key tenet of sustainable tourism is that there must be balance between the three dimensions. Therefore, rather than shifting from overemphasizing the economic impacts of tourism to overemphasizing the social and environmental impacts of tourism, economic value is as important as social and environmental values. This is evidenced in practice, as the UN World Tourism Organization (UNWTO) publishes "Tourism Highlights" annually and reports on income 
earned, tourist arrivals, market shares, and jobs created by tourism [9]. Without tourists visiting the place and the subsequent economic activity, there is no tourism and there cannot be positive or negative impacts. Thus, understanding how to attract tourists and how to ensure continual tourism demand is critical for destinations to ensure sustainable earnings. This can be achieved, in large part, by understanding tourists' perceptions and experiences. When a destination attracts a stable numbers of tourists, the destination is better equipped to survive intense competition with other destinations. To be a sustainable destination, it is critical that the destination also minimizes the negative impacts of tourism on the host community and environment.

The success and failure of a destination depends, in part, on tourists' evaluation of the destination. Destination attributes are what a destination can offer and what the destination has offered. Prior to travel, people choose a destination based on their expectations of the destination. In other words, people consider what the destination can offer and the potential experience they will have at the destination [10]. Post travel, people evaluate the destination based on what the destination offered them during their visit $[11,12]$. Destination attributes are one of the most fundamental elements of tourists' evaluation a destination. Hence, destination managers need to understand the importance of a destination's attributes. They should able to determine which destination attributes offer better value to tourists and make the destination more attractive. Academics in tourism have utilized destination attributes in many contexts, ranging from defining a destination [13], to constructing destination image [14-16], to examining importance and destination performance $[17,18]$, to understanding competitiveness of a destination [19]. Furthermore, tourism academics have also examined the impact of destination attributes on tourists' satisfaction, intentions to visit, and word of mouth (WOM) recommendations [20]. While each research context is different, the goal of investigating destination attributes is to better understand a destination and to distinctively position it in an increasingly saturated global tourism market. More importantly, accessing what are the destination attributes that make destination attractive and competitive is critical for the destination to achieve economic sustainability [21].

Until recently, researchers examining destination attributes have relied on conventional survey methods with structured formats and pre-established dimensions that tourists were asked to rate (i.e., [20-22]) based on their expectation and experience with destination offerings. However, the structured evaluation method may hinder tourists from freely expressing their experience [23,24]. On the other hand, tourists' reviews and comments are more realistic in that tourists write based on their true experience in a specific destination [25]. Therefore, examining destination attributes from tourists' online reviews may provide an opportunity to more accurately capture the attributes from the tourists' perspective. Determining destination attributes through online reviews can be particularly beneficial to micro-level destinations, where management faces difficulty in securing the financial and human resources needed to investigate and analyze the destination attributes offered. Macro-level destination management organizations, such as national tourism organizations, may also lack the budgetary resources needed to conduct a comprehensive destination attribute survey for all of their key tourist origin markets [26-28]. Regardless of the size of the destination management organization, destination managers are responsible for offering valuable destination attributes that, in turn, can result in the enhancement of tourists' experiences in the destination.

This study primarily examines the destination offerings of a micro-level destination by identifying salient destination attributes from tourist' comments about a destination that they posted on an online travel community. Specifically, this study aims to determine which destination attributes are positively influencing the tourists' behavior and attitudes by exploring the attributes in relation to intention to visit/recommend, overall positive attitude, and overall ranking given in the online travel community. One of the purposes of this destination- and context-specific study is to serve the micro-level destination's need to analyze its current offerings to the tourist and to develop an effective experience management strategy. 


\section{Study Background}

\subsection{Destination Attributes for Evalutating Destination}

Destination attributes are a fundamental research concept in tourism because a destination consists of multiple destination attributes [29]. Coltman [13] defines a destination as "an area with different natural attributes, features, or attractions" (p. 4). It can be simply understood that destinations in many different levels-a micro attraction like a site to a macro attraction like a city and a country-in any areas with its unique attributes are destinations. More specifically, "a destination at a very local level" [30], like a single attraction, is a destination that tourists can evaluate based on intangible and tangible attributes [1]. It is important to remember that regardless of the size or locale of tourist destinations, all destinations are based on the destination attributes they offer.

As a fundamental research concept, destination attributes have been investigated in relation to many other focal research concepts in tourism. Most tourism researchers view destination attributes as a key element to the construct of destination image [31-34]. In that regard, Ritchie and Crouch [35] explained destination image as a result of evaluations based mainly on the destination's physical attributes. Thus, when investigating the destination image, scholars use multiple sets of destination attributes to measure the construct. However, depending on the scholars, there have been differences in how destination attributes have been classified $([27,33,34])$. Echtner and Ritchie [29], in their most cited destination image research, classified destination attributes on a continuum of functional (physical) to psychological. Some may support the view that destination image is based on an evaluation of physical attributes [35], which is a cognitive component of destination image [36]. However, according to Baloglu and McCleary's [31] definition of the cognitive and affective image in relation to place attributes, attributes are a foundation for both images of destination attributes that are cognitively evaluated and then the affective response to the cognitive destination attribute evaluation. One other classification of destination attributes is based on functional (tangible), psychological (abstract), and conative components [37]. This classification is consistent with Echtner and Ritchie's [29] classification, but also includes a conative component (i.e., tourists' behavioral intention to visit and to recommend the destination to others).

The critical role of destination attributes is also evidenced in other popular research concepts in tourism. Destination attributes can also be a reason for tourists to decide to visit a destination. Scholars have researched this perspective in terms of destination motivation [38-40]. This perspective is described in one of the most popular motivation theories-push and pull [39,41,42]. The pull side of motivation, in particular, is closely related to destination attributes. The theory explains that tourists' motivation to travel are based on a combination of pull factors, such as socio-psychological motivation (i.e., escaping, relaxation, relation, self-esteem, and others) [17,38], and push factors, which are related to destination attributes (i.e., natural and historical resources, tourism infrastructure and facilities, transportation, climate, and others) [41,43,44]. According to Klenosky's [45] explanation of the push and pull theory, push factors answer "where to go" and pull factors answer "whether to go". Destination attributes may not be a sole reason for people to travel; however, it is important to determine the role of destination attributes role in tourists' decision to travel to a specific destination (i.e., destination choice).

Almost all destinations aim to achieve destination competitiveness by attracting potential tourists and increasing tourist visitation, which will consequently lead to tourist expenditures [35]. While researchers agree that being a competitive destination is important, they have not agreed on determinants for measuring destination competitiveness [46,47]. The determinants used in destination competitiveness studies include attributes such as price competitiveness [48], environmental competitiveness [49], strategic destination marketing and management [50,51], and destination positioning [52]. Utilizing these determinants, researchers have either diagnosed the destination competitiveness of a single destination $[19,53,54]$ or compared two or more destinations $[20,55-58]$. While there are various ways to measure destination competitiveness, destination attributes have 
consistently been included as an integral factor in each measurement. Ritchie and Crouch [35]'s competitive destination model includes physical destination attributes in their 'supporting factors and resource' and 'core resources and attractors' sections. The resources in their model are conceptualized to be a foundation of destination competitiveness. Similarly, Dwyer and Kim [56] and Dwyer et al. [37] included natural, heritage, created, and supporting resources as a primary factor of destination competitiveness. These two models also showed that destination management, policy, planning, and development are important factors as well. However, they indicated that these come after the existence of resources (i.e., destination attributes).

Another area of study in tourism that uses destination attributes as a foundation is the Important and Performance Analysis (hereafter, IPA) concept. The model has been favored by various public and private tourism service providers to determine their positioning and performance in the market [59]. The IPA, based on the salient destination attributes that a destination offers to tourists, allows tourists to evaluate how important those destination attributes are and then judge how well the destination performed on the same destination attributes $[17,60]$. The difference between importance and performance helps destination managers identify destination attributes that they can enhance to achieve competitive advantage, as well as destination attributes that should be improved [59]. Further, the result of IPA can be a useful tool for the marketing and management strategy [61-63]. Like the competitive destination model, destination attributes have been found to be an essential element in determining the destination importance and performance.

The review of the aforementioned concepts in tourism research has evidenced the critical role of destination attributes in assessing tourists' perceptions of a destination. In summary, tourists' evaluation of destination attributes has been used in determining destination image, destination choice motivations, destination competitiveness, and destination importance and performance. Thus, destination attributes have served to be an excellent indicator for better managing a destination. Specifically, destination managers can identify which attributes contribute to the current destination attractiveness and to negative tourist experiences. Regardless of the context, investigations of destination attributes can provide meaningful implications for the industry by providing strategic direction, as well as to the destination literature by utilizing theoretically driven destination attributes.

\subsection{Tourists' Experiences and Destination Attributes on Social Media}

The evolution of web 2.0, which enables users to process digital content, changed tourists' travel patterns. As a result, tourists can now share their travel experiences by writing reviews and posting photos and videos on a social media site instantly and frequently. This can be done during two phases of the travel experience- while they are the destination and after they return home. Consequently, the role of the tourist has shifted from the tourist as an information receiver to the tourist as an active player that creates and generates information about the destination [64]. A major implication of this shift is that the destination content that is generated by the actual visitor can reach the 'tourist-to-be' [23], who may view the content and may decide to go to the destination featured in the content. While destination management organizations' (DMOs) primary task is to provide information and promote the destination to the 'tourist-to-be,' tourists validate and trust the tourist's review more than service providers' content. Traditionally, word of mouth (WOM) was found to be influential in potential tourists' decisions. As a result of web 2.0, the tourist review served to be the new word of mouth, which is referred as e-WOM because it is shared electronically. In the age of e-WOM, tourists have started to plan their own trips and customize it, rather than relying on travel agents [65]. The tourist-to-be pays attention to the other tourists' description of the destination attributes and expressions about their experience with those attributes. In this digital age, tourists have become their own tour agency, content provider, receiver, and reviewer. The phenomenal change, has had a significant influence on DMOs and tourism businesses. Both product and service providers are challenged with promotional and quality issues. The immeasurable amount of information that tourists provide on the Internet and social media cannot be controlled by tourism suppliers [66]. Thus, the DMO and tourism businesses 
do not have much room for "place-myths" $[67,68]$ to make a destination more favorable. Examples of this include slight exaggerations and photo editing images [69].

The aforementioned challenge has been examined in some tourism studies by investigating the content generated by tourists and DMOs. For example, a study conducted by Svetlana and Zhan [70] compared the content generated by both tourists and the DMO to identify the difference in destination image, using pre-identified destination attributes. The study findings indicated that DMOs acknowledged that what tourists may see as attractive in a destination may be different from what the DMO promotes on the Internet. The researchers concluded that while DMOs may attempt to promote the destination as well-rounded, by featuring various destination attributes, tourists exhibit strong interest in specific characteristics of the destination. Additionally, a recent study illustrating the important role of tourist-generated content in destination marketing and promotion suggests that tourism providers acknowledge that tourists are opinion makers and include their opinions when shaping their destination promotional strategy [66]. In this case, tourists are viewed as co-creators. Inclusion of tourists' opinions in business and business strategy is encouraged by the mainstream consumer research [71]. This notion is called co-creation. The core concept of co-creation is to take consumers' opinions and use them to improve a product, service, and quality control [72].

Furthermore, in the digital age, the consumer has a strong voice and it is inevitable that user generated content (UGC) will be shared by other people in the world [2]. In tourism, the tourist can shape a strong opinion and voice their opinion via online reviews on TripAdvisor, a photo shared on Instagram and Facebook, and posts made on a personal blog [73]. In each of these examples, tourism businesses have no control over the dissemination of information related to their destination, which can influence others' perceptions of the destination. Thus, tourism product and service providers should also utilize tourists' opinion on the Internet and social media to analyze their current business status. The results should then be utilized to enhance and improve their product or service. This type of analysis is a great tool for tourism business to diagnose their product competitiveness and attractiveness from the important perspective of the tourist. In particular, a small tourism business or local DMO with limited resources to hire an expert to diagnose their management and marketing strategy can benefit from the freely available data on the Internet and social media, if they know what and how it should be analyzed and interpreted.

Use of digital data generated by tourists in research can serve as a substitute for the structured survey, which is completed based on pre-established dimensions [74]. Survey methodology has received a fair share of criticism because it limits the tourists' response about their perceptions of and experiences in destination within the provided structure $[23,24]$. Survey methodology has also been criticized because the respondent can become exhausted [75]. This, in turn, can result in poor response rates $[75,76]$. On the other hand, examination of UGC has been favored by researchers because of its ability to capture tourists' real opinions about and perceptions of the destination experience (c.f. [74,77]). Accordingly, UGC may be a better tool to observe the fundamental source of tourists' satisfaction and dissatisfaction with their trip and the destination. In this sense, identifying the destination attributes that tourists discuss in their review of a destination can help both researchers and practitioners better understand tourists' experience in the destination. More specifically, researchers and practitioners may better understand the source of tourists' negative and positive experiences.

\subsection{Purpose and Research Questions}

The primary purpose of this study is to investigate tourists' perceptions of destination offerings for a micro-scale tourist site based on their written review of their experience on social media. In this study, a micro-scale tourist site-a local attraction —was chosen as a destination because, (1) by the definition of destination given by Coltman [13], an attraction is also a destination; and (2) micro-destinations have received relatively less attention than macro-scale destinations [1]. By conducting this study, the researchers hope to demonstrate how destination managers can identify the destination attributes that are critical to the visitors' experiences and use it in their strategic planning. This could, in turn, 
enhance the destination's competitive edge. To address the purpose, this study aims to answer the following research questions:

(1) What are the destination attributes that are salient in tourists' reviews of the tourist site on social media?

(2) What are the destination attributes offered by the tourist site that tourists have a positive experience with? Further, how are these positive destination attributes associated with one another?

(3) How do tourists with different experiences on each destination attribute (positive vs. not-positive) evaluate the tourist site based on a star-rating system?

(4) Is there consistency between tourists' satisfaction based on star ratings and their expressed opinions in the written reviews? More specifically, do tourists' overall star ratings match the behavior and attitudes expressed in their written reviews?

\subsection{Study Location}

The study location is a historic tourist site (hereafter called HTS) located at the heart of a city that is on the Northeastern coast of Florida (hereafter called CITY). This city is known as the Nation's Oldest City and is listed as a National Historic Landmark by the National Park Service for the longest continually inhabited European-founded city in the United States [78]. The city's rich history has been linked to Spanish, English, Greek, Native American, and African American inhabitants since the sixteenth century. The HTS is located in the city's historic district. Visitors to the HTS can experience the heritage of the city's Spanish and English settlements with guided tours or self-exploration of the architecture, reenactments, and era-specific exhibitions. The HTS offers visitors the opportunity to climb a watch tower where they can see the town and the waterfront fort, which is a significant historic tourist attraction in the city. The HTS also has an extra sitting space with a stage under a large oak tree where a small-to-medium sized meeting or event can be hosted. Additionally, there is a restaurant and bar that is part of the HTS' property and management, which is open to the city's main historic street. The HTS was chosen to assist the local administration in its improvements efforts to enhance the visitor experience for an increasing number of visitors. The improvement efforts were also linked to the local administration's goal of ensuring sustainable economic impacts of tourism. As requested by tourism stakeholders, the name of the HTS will not be revealed.

\section{Method}

This study investigates the destination attributes experienced by visitors to the study site. It examines destination attributes visitors highlighted in their written comments on social media. The narratives based on real experiences provided the researchers with a unique opportunity to understand the predominant attributes that emerged in online discussions among visitors. The research design consisted of several processes. First, the researchers collected the comments about the study site posted on a travel-related social media site. Data were then coded in accordance with pre-established coding themes. The coding process followed a content analysis approach based on Echtner and Ritchie's [29] continuum of functional (physical) to psychological attributes. After ensuring the reliability of the coded data, a series of analyses were performed. Further details about the methodology employed in this study are explained in the following subsections.

\subsection{Data Source Selection}

TripAdvisor (www.tripadvisor.com) was chosen to retrieve reviews written by visitors. TripAdvisor is one of the most recognized and active online travel communities $[73,79,80]$ that is visited by 435 million visitors monthly on average and the reviews on 7 million businesses (e.g., hotels, restaurants, and attractions) are accumulated to the total of 390 million [81]. The information about the business and reviews on Social Networking Service (SNS) has a significant influence on tourists' decision making process [82]. 
For the study data, the most recent 500 TripAdvisor reviews posted by visitors to the HTS and the site's overall rating score given by these reviewers were collected. These data were posted between 12 March 2014 and 12 October 2015. A total of 487 reviews were used for the analysis. Thirteen reviews were excluded from this study because they were irrelevant (e.g., some reviews were not written about the HTS, but were overall reviews for the city and the city's main historic street).

\subsection{Category Development}

The authors used the studies conducted by Echtner and Ritchie [29] as the theoretical grounding when formalizing the category sets used in the content analysis to determine the destination attributes expressed in the reviews. Based on Echtner and Ritchie's work, categories were developed based on the functional and psychological characteristics of the destination. Additionally, to determine the influence of the characteristics on the behavior and attitude of visitors, a third category was added. As a result, there were three main categories-"psychological characteristics" for intangible attributes; "functional characteristics" for tangible attributes; and "conative characteristics" for attitude and behavior-related attributes. Psychological and functional characteristics had three broad first-tier categories, with several second-tier categories. For psychological characteristics, "Quality of Experience", "Atmosphere", and "Target Market" were identified as the first-tier categories, while "Attractions", "Activities", and "Amenities" were identified as first-tier categories for functional characteristics. The coding categories are provided in Table 1.

Table 1. Coding categories for Psychological, Functional, and Conative elements.

\begin{tabular}{|c|c|c|c|}
\hline & Category & & Category \\
\hline \multirow{10}{*}{ 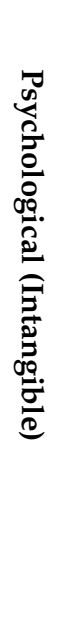 } & Quality of Experience & \multirow{12}{*}{ 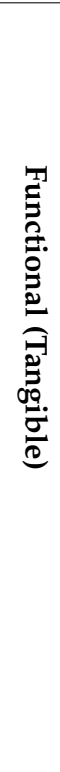 } & Attractions (Seeing) \\
\hline & Tour Guiding Excellence & & Architecture/Building (Design) \\
\hline & Educational Experience & & Watch Tower (View) \\
\hline & Value for Cost/Time & & Ship Building Process (Exhibition) \\
\hline & Other * & & Demonstrative Activities \\
\hline & Atmosphere & & Other \\
\hline & Historic and Authentic & & Activities (doing/experience) \\
\hline & Other & & $\begin{array}{l}\text { Historic Adventure Tour } \\
\text { Participation }\end{array}$ \\
\hline & $\begin{array}{l}\text { Target Market } \\
\text { Family-Oriented } \\
\text { Child-Friendly } \\
\text { All Age Groups/Adult }\end{array}$ & & $\begin{array}{l}\text { Tea-Time Tour Participation } \\
\text { Interactive Activities } \\
\text { Self-Guided Tour } \\
\text { Other }\end{array}$ \\
\hline & Other & & Amenity \\
\hline \multirow{2}{*}{ ?ִ } & $\begin{array}{l}\text { Behavior } \\
\text { Attitude }\end{array}$ & & \multirow{2}{*}{$\begin{array}{l}\text { Food and Beverage/Restaurant } \\
\text { Extra Service Quality } \\
\text { Additional Service Amenity }\end{array}$} \\
\hline & TripAdvisor Star Rating & & \\
\hline
\end{tabular}

\subsection{Data Coding}

All data were coded by two coders who followed the formal coding guide. Each review was first evaluated to determine whether the post fit within the psychological (intangible) or functional (tangible) attribute categories. If the review fit within the category, it was coded as "1" (present). If the review did not fit within the category, it was coded as " 0 ". Next, the reviews were evaluated to determine whether the post fit within the behavior or attitude categories. If the review fit within the category, it was coded as " 1 " (present). If the review did not fit within the category, it was coded as " 0 ". Reviews coded as " 1 " present were then coded again based on the favorability. If the review had 
a negative tone when mentioning the category, it was coded as " 1 " (negative). If the review had a neutral tone when mentioning the category, it was coded as "2" (neutral). If the review had a positive tone when mentioning the category, it was coded as " 3 " (positive). Therefore, when taking the two coding processes together, the coding ranged from 0 to 3 for behavior and attitude (see Table 2).

Table 2. Coding instruction summary.

\begin{tabular}{ccccc}
\hline \multicolumn{2}{c}{ Coding Approach I } & & Coding Approach II ${ }^{\mathbf{2}}$ & \\
Coding Category & Coding Value & Coding Category & Sub-Coding Category & Coding Value \\
\hline Present & 1 & Present & Positive & 3 \\
& & & Neutral & 2 \\
Not present & 0 & Not present & Negative & 1 \\
\hline
\end{tabular}

${ }^{1}$ Coding approach employed for functional, psychological, and conative category; ${ }^{2}$ Coding approach employed for conative category (behavior and attitude).

Krippendorff's Alpha was used as the reliability measure to assess the agreement between two coders with respect to the clarity and consistency of coding. During the preliminary category development, the coders re-examined the categories with low reliability. After the re-evaluation of intercoder reliability, the categories and coding guide were considered satisfactorily objective (Table 3). The coefficient of 0.81 or greater is almost perfect and the range of 0.61 to 0.80 is substantial [83].

Table 3. Inter-coder reliability results.

\begin{tabular}{|c|c|c|c|c|c|}
\hline & Category & Reliability & & Category & Reliability \\
\hline \multirow{12}{*}{ 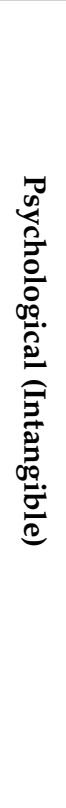 } & Quality of Experience & & \multirow{15}{*}{ 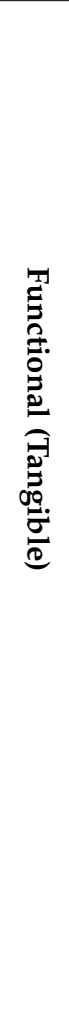 } & Attractions (Seeing) & \\
\hline & $\begin{array}{l}\text { Tour Guiding } \\
\text { Excellence }\end{array}$ & 0.967 & & $\begin{array}{l}\text { Architecture/Building } \\
\text { (Design) }\end{array}$ & 0.936 \\
\hline & $\begin{array}{l}\text { Educational } \\
\text { Experience }\end{array}$ & 0.883 & & Watch Tower (View) & 0.986 \\
\hline & Value for Cost/Time & 0.881 & & Ship Building Process & 0.982 \\
\hline & Other ${ }^{1}$ & 1.000 & & $\begin{array}{c}\text { Demonstrative } \\
\text { Activities }\end{array}$ & 0.928 \\
\hline & Atmosphere & & & Other & 0.934 \\
\hline & $\begin{array}{c}\text { Historic and Authentic } \\
\text { Other }\end{array}$ & 0.975 & & $\begin{array}{c}\text { Activities } \\
\text { (doing/experience) } \\
\text { Historic Adventure } \\
\text { Tour Participation }\end{array}$ & 0.889 \\
\hline & Target Market & & & $\begin{array}{l}\text { Tea-Time Tour } \\
\text { Participation }\end{array}$ & 0.998 \\
\hline & Family-Oriented & 0.936 & & Interactive Activities & 0.947 \\
\hline & Child-Friendly & 0.893 & & Self-Guided Tour & 0.940 \\
\hline & All Age Groups/Adult & 0.957 & & Other & 0.996 \\
\hline & Other & 0.959 & & Amenity & \\
\hline \multirow{3}{*}{ ْి } & Behavior & 0.832 & & $\begin{array}{c}\text { Food and } \\
\text { Beverage/Restaurant }\end{array}$ & 0.951 \\
\hline & Attitude & 0.900 & & Extra Service Quality & 0.977 \\
\hline & $\begin{array}{c}\text { TripAdvisor Star } \\
\text { Rating }\end{array}$ & N/A & & $\begin{array}{c}\text { Additional Service } \\
\text { Amenity }\end{array}$ & 0.957 \\
\hline
\end{tabular}

${ }^{1}$ There were no contents to be counted for "Other" in Quality of Experience. Thus, coders all recoded " 0 ". Therefore, the intercoder reliability was 1.000 . For further analysis, the category was removed. 


\section{Results}

\subsection{Representation of Destination Attributes}

The coding results, as illustrated in Table 4, revealed that some of the site's attributes were more salient than others. The quality of tour guides (Tour Guiding Excellence) and being a part of a historic tour (Historic Adventure Tour) were mentioned noticeably more often (both over 340 counts) than the other attributes. Both of these categories are related to the HTS management company's tour program. Of all of the attributes, the quality of the tour guide was the most noticeable attribute that visitors discussed. As the HTS offers a historic walking tour, visitors to the HTS reflected on their tour program experiences in their reviews. The next most frequently mentioned attributes were Educational Experience and Child-Friendly (both over 100 counts). This clearly illustrates that visitors often associate the HTS with providing opportunities for learning. This educational attribute could be related to the child-friendly attribute, as visitors may think that the HTS is a good place to bring children because it has opportunities for children to learn about history. Following the abovementioned attributes, Historical/Authentic, Value for Cost/Time, and Family-Oriented were mentioned more frequently than the rest of the site attributes. It is not surprising that visitors perceived the HTS to have a historic and authentic atmosphere. The attraction includes a real historical building and other buildings that look like they are from the historical era, as well as some replica artifacts. It is likely that the historical setting of the HTS and the accompanying guided tour lead the visitor to perceive that the place is historic and authentic. It is common for visitors to discuss whether the HTS is worth the money or not when the site has an admission fee. The results also reveal that visitors value the HTS as a place where families can visit.

The most frequently mentioned site attributes primarily fall within the psychological attributes category. A relatively smaller proportion of the site attributes fall within the function attributes category. Except for the Historical Adventure Tour Participation category, visitors mentioned physical attributes almost as frequently as the Demonstrative Activities, Food and Beverage/Restaurant, Architecture/Building, Self-Guided Tour, and Interactive Activities categories. Comparing the frequency of the Self-Guided Tour category to the Historic Adventure Tour Participation category indicates that the HTS has a strong identity as a site where the guided tour is worth it. Based on the initial coding approach, not many details about the physical aspects of the HTS were mentioned. Rather, it revealed that the guided tour and the quality of the tour guide are the most salient site attributes.

The initial coding process for the conative attributes showed that visitors mentioned their behavior in terms of whether they will come back to or recommend the HTS. In order to better understand visitors' behaviors and attitudes, the reviews were categorized as having a negative, neutral, or positive tone. For the Behavior (except reviews without any indication of behavior) and Attitude categories, a majority of the reviews were written in a positive tone. Additionally, visitors' star ratings were evaluated. This evaluation revealed that visitors mostly rated their experience at the HTS as excellent. At face value, the star ratings seem to reflect the positive behavior and attitude captured in visitors' written reviews. 
Table 4. (A) Frequency of coding approach I. (B) Frequency of coding approach II.

\begin{tabular}{|c|c|c|c|c|c|c|c|}
\hline \multicolumn{8}{|c|}{ (A) Coding Approach I } \\
\hline & Variable & $\begin{array}{l}\text { Freq. of Positive } \\
\quad(N=487)\end{array}$ & Percentage & & Variable & $\begin{array}{l}\text { Freq. of Positive } \\
\quad(N=487)\end{array}$ & Percentage \\
\hline \multirow{12}{*}{ 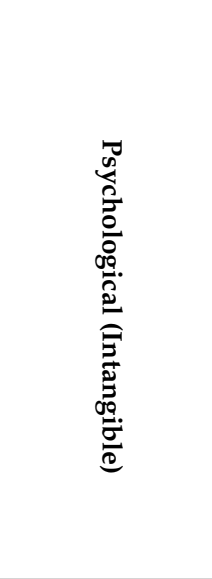 } & Quality of Experience & & & \multirow{16}{*}{ 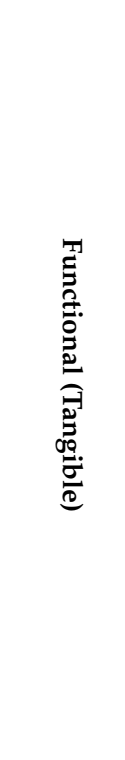 } & Attractions (seeing) & & \\
\hline & Tour Guiding Excellence & 343 & $70.4 \%$ & & $\begin{array}{l}\text { Architecture/Building } \\
\text { (Design) }\end{array}$ & 41 & $8.4 \%$ \\
\hline & Educational Experience & 128 & $26.3 \%$ & & Watch Tower (View) & 27 & $5.5 \%$ \\
\hline & Value for Cost/Time & 79 & $16.2 \%$ & & Ship Building Process & 10 & $2.1 \%$ \\
\hline & Atmosphere & & & & Demonstrative Activities & 55 & $11.3 \%$ \\
\hline & Historic and Authentic & 98 & $20.1 \%$ & & Other & 40 & $8.2 \%$ \\
\hline & Other & 12 & $2.5 \%$ & & $\begin{array}{c}\text { Activities } \\
\text { (doing/experience) }\end{array}$ & & \\
\hline & Target Market & & & & $\begin{array}{c}\text { Historic Adventure Tour } \\
\text { Participation }\end{array}$ & 342 & $70.2 \%$ \\
\hline & Family-Oriented & 76 & $15.6 \%$ & & Tea-Time Tour Participation & 7 & $1.4 \%$ \\
\hline & Child-Friendly & 141 & $29.0 \%$ & & Interactive Activities & 38 & $7.8 \%$ \\
\hline & All Age Groups/Adult & 42 & $8.6 \%$ & & Self-Guided Tour & 39 & $8.0 \%$ \\
\hline & Other & 19 & $3.9 \%$ & & Other & 1 & $0.2 \%$ \\
\hline \multirow{4}{*}{ 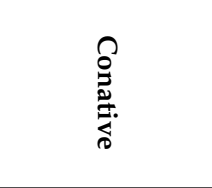 } & Behavior & 131 & $26.90 \%$ & & Amenity & & \\
\hline & Attitude & 432 & $88.70 \%$ & & $\begin{array}{c}\text { Food and } \\
\text { Beverage/Restaurant }\end{array}$ & 42 & $8.6 \%$ \\
\hline & TripAdvisor Star Rating * & N/A & N/A & & Extra Service Quality & 22 & $4.5 \%$ \\
\hline & & & & & Additional Service Amenity & 25 & $5.1 \%$ \\
\hline \multicolumn{8}{|c|}{ (B) Coding Approach II } \\
\hline & \multicolumn{2}{|c|}{ Behavior } & \multicolumn{2}{|c|}{ Attitude } & \multicolumn{3}{|c|}{ Star Rating } \\
\hline & Freq. & Valid \% & Freq. & Valid \% & & Freq. & Valid \% \\
\hline $0=$ Not present & 338 & 69.4 & 5 & 1.0 & $1=$ Terrible & 6 & 1.2 \\
\hline $1=$ Negative & 7 & 1.4 & 27 & 5.5 & 2 = Poor & 8 & 1.6 \\
\hline $2=$ Neutral & 11 & 2.3 & 23 & 4.7 & $3=$ Average & 39 & 8 \\
\hline \multirow[t]{2}{*}{$3=$ Positive } & 131 & 26.9 & 432 & 88.7 & $4=$ Very Good & 90 & 18.5 \\
\hline & & & & & $5=$ Excellent & 344 & 70.6 \\
\hline Total & 487 & 100.0 & 487 & 100.0 & Total & 487 & 100 \\
\hline
\end{tabular}

${ }^{*}$ TripAdvisor star rating ranges from $1=$ terrible, $2=$ poor, $3=$ average, $4=$ very good, to $5=$ excellent 


\subsection{Destination Attributes Mapping for Co-Occurrence}

In visitors' reviews of the HTS, certain attributes were captured concurrently. To understand the composition and connection of these attributes in visitors' minds, the co-occurrences were visualized in Figure 1. This approach was employed following the work of Li and Stepchenkova [84] and Stepchenkova, Kim and Kirilenko [85]. The bubbles indicate the frequency presented in Table 1. The bubbles for attributes with frequencies over 100 were colored in grey and those with less than 100 were colored in white. The lines indicate the probability of the actual co-occurrence of any two attributes different from the probability of the expected co-occurrence. To estimate the probability of co-occurrence between Attribute 1 (A1) and Attribute 2 (A2), first the probability that $p_{a 1}$ of Attribute 1 and $p_{a 2}$ of Attribute 2 appear independently in a TripAdvisor review is calculated as the ratio of the frequency of Attribute $1\left(f_{a 1}\right)$ and Attribute $2\left(f_{a 2}\right)$ appearing in the total TripAdvisor review sample size (c.f. sample size is denoted as $\mathrm{N}$ ). This is estimated as $f_{a 1} / \mathrm{N}$ and $f_{a 2} / \mathrm{N}$, respectively. Second, the probability of both A1 and A2 appearing simultaneously in a TripAdvisor review, indicating the probability of co-occurrence between $\mathrm{A} 1$ and $\mathrm{A} 2$, is calculated by $p_{a 1} * p_{a 2}$ and denoted as $p_{a 1} p_{a 2}$. Further, based on the assumption of independence of any two attributes, A1 and A2 and the number of $\mathrm{A} 1$ and $\mathrm{A} 2$ co-occurrence is random, variable $f_{a 1 a 2}$ that is binomially distributed, probabilities of $\mathrm{A} 1$ and A2 ( $\left.p_{a 1} p_{a 2}\right)$, and sample size can be used to calculate the expected value and variance [86]. Expected value $\left(\mathrm{E}=\mathrm{N} p_{a 1} p_{a 2}\right)$ and variance $\left(\operatorname{Var}=\mathrm{N} p_{a 1} p_{a 2}\left(1-p_{a 1} p_{a 2}\right)\right)$ were used, yielding the $\mathrm{z}$-score, which is the determinant to judge whether the actual co-occurrence score of two attributes $\left(f_{a 1 a 2}\right)$ is significantly different from the expected co-occurrence score of two attributes. Accordingly, a z-score is calculated using the following formula:

$$
Z=\frac{f_{a 1 a 2}-E}{\sqrt{V a r}}
$$

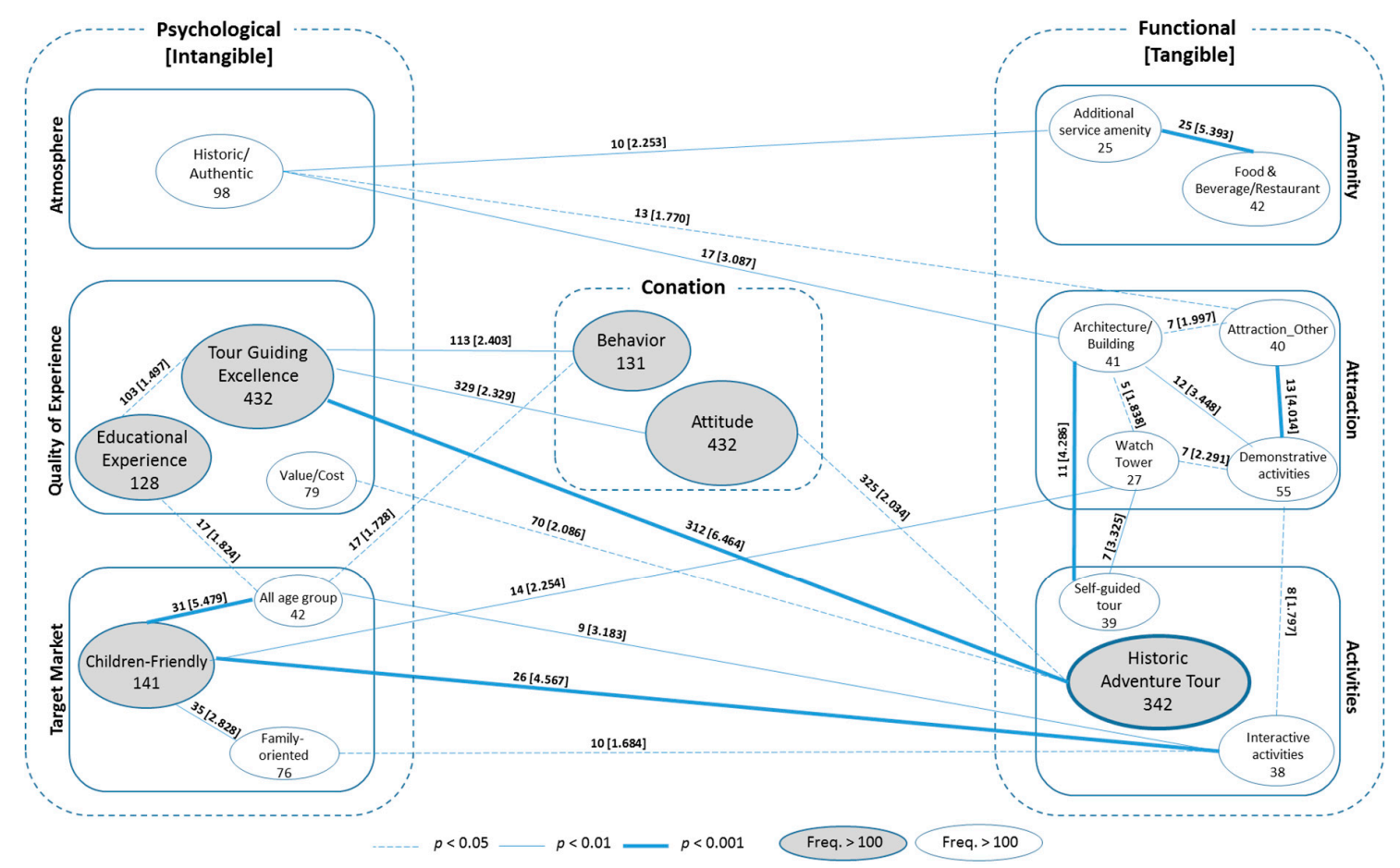

Figure 1. Destination co-occurrence map based on Psychological, Functional, and Conative dimensions.

Assuming normally distributed random variables, the z-scores were compared with critical $\mathrm{z}$-scores for non-directional hypotheses at the significance level of $0.001,0.05$, and 0.01 (zcrit $=3.5,2.58$, 
and 1.96, respectively) [87]. Larger z-scores in absolute value would indicate that the independence of the two attributes is unlikely, meaning that visitors are likely to mention two attributes when they write about their experience at the HTS. In Figure 1, thick solid lines represent the link between the pairwise relationships among the attributes when the z-score is greater than $3.5(p<0.001)$. Additionally, a pairwise association with a z-score greater than $2.58(p<0.01)$ and $1.96(p<0.05)$ are presented as a thin solid line and a dashed line. The two numbers presented above the line are the frequency of co-occurrence between pairwise attributes and a respective z-score. The square box with a dashed line indicates the distinction between HTS attribute groups-Psychological, Functional, and Conative. Additionally, the box with a thin solid line within the dashed line, square box represent the sub-attribute dimension.

Figure 1 reveals some distinctive relationships between two pairs of attributes presented. The most noticeable link shown is between Tour Guiding Excellence and Historic Adventure Tour. Specifically, when visitors mention participation in a Historic Adventure Tour offer at the HTS, they significantly talk about the Tourist Guiding Excellence. Another significant link shown is between Child-Friendly and Interactive Activities. This indicates that when visitors encounter interactive activities at the HTS, they associated the HTS with being a child-friendly place. Being a child-friendly place in the visitors' mind is also closely associated with All Age Groups. This indicates that visitors perceived the HTS as a place for all ages to visit. The strong association between Self-Guided Tour and Architecture/Building indicates that visitors who toured the HTS by themselves like to discuss the exterior aspects of the HTS' buildings more than other attributes.

Other links that are associated with the most frequently mentioned attributes are the association between Historic Adventure Tour and Value/Cost because of the visitors' tendency to comment about the value of the admission fee for the guided tour. Educational Experience was associated with both Tour Guiding Excellence and All Age Groups. This indicates that educational value can be provided to visitors of all ages and the quality of the tour guide can contribute to the educational experience.

Finally, in terms of the association with conative dimensions, there were a few links that indicate a significant association. Tour Guide Excellence and Historical Adventure Tour were linked to Attitude in that when visitors indicate that they participated in a historic adventure tour and mention the quality of the tour guide, they tend to express their attitude related to their experience. Behavior also shows a few links between All Age Groups and Tour Guiding Excellence. It is mentioned that the HTS is worth revisiting and recommending to others when the HTS is perceived to be for all age groups. Additionally, the quality of the tour guide was significantly associated with visitors' intentions to revisit and recommend the HTS to others. At least one attribute from Quality of Experience, Target Market, and Activities were linked to the Conative dimension. Atmosphere, Amenity, and Attraction were not found to have a significant association with the Conative dimension. This indicates that visitors discuss these attributes in relation to others; however, they may not be the central focus of visitors' attitude and behavior.

\subsection{Destination Attribute Differences and Influence}

Mann-Whitney $U$ test was conducted to determine the level of satisfaction between the positive group and non-positive group based on the star rating given by reviewers on TripAdvisor. The result of Mann-Whitney $\mathrm{U}$, shown in Table 5, indicated that there was a significant difference in satisfaction for Tour Guiding Excellence, Education Experience, Historic Adventure Tour Participation, and two of the Conative variables-Behavior and Attitude $(p<0.001)$. Additionally, groups showed a marginal difference for Historical/Authentic and Family-Oriented $(p<0.01)$. However, most of the attributes were not found to differ between the positive and non-positive groups. 
Table 5. Positive vs. negative group on destination attributes and behavioral/attitudinal consequence.

\begin{tabular}{|c|c|c|c|c|c|c|c|c|}
\hline & \multirow[b]{2}{*}{ Variable } & \multicolumn{2}{|c|}{$\begin{array}{l}\text { Positive } \\
\text { Group (1) }\end{array}$} & \multicolumn{2}{|c|}{$\begin{array}{l}\text { Negative } \\
\text { Group (2) }\end{array}$} & \multirow[b]{2}{*}{$\begin{array}{c}\text { Mann-Whitney } \\
\text { U }\end{array}$} & \multirow[b]{2}{*}{$\mathbf{Z}$} & \multirow[b]{2}{*}{$p$-Value } \\
\hline & & $\mathbf{N}$ & $\begin{array}{l}\text { Mean } \\
\text { Rank }\end{array}$ & $\mathbf{N}$ & $\begin{array}{l}\text { Mean } \\
\text { Rank }\end{array}$ & & & \\
\hline \multirow{9}{*}{ 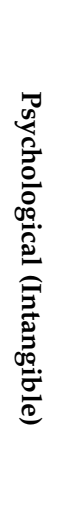 } & $\begin{array}{l}\text { Quality of } \\
\text { Experience }\end{array}$ & & & & & & & \\
\hline & $\begin{array}{l}\text { Tour Guiding } \\
\text { Excellence }\end{array}$ & 343 & 269.40 & 144 & 182.92 & $15,901.000$ & -7.753 & 0.000 \\
\hline & $\begin{array}{l}\text { Educational } \\
\text { Experience }\end{array}$ & 128 & 258.73 & 359 & 238.75 & $21,090.500$ & -1.723 & 0.000 \\
\hline & Value for Cost/Time & 79 & 252.62 & 408 & 242.33 & $15,435.000$ & -0.743 & 0.457 \\
\hline & $\begin{array}{c}\text { Atmosphere } \\
\text { Historic/Authentic }\end{array}$ & 98 & 261.04 & 389 & 239.04 & $17,391.000$ & -1.676 & 0.094 \\
\hline & Target Market & & & & & & & \\
\hline & Family-Oriented & 76 & 263.57 & 411 & 240.38 & $14,131.000$ & -1.648 & 0.099 \\
\hline & Child-Friendly & 141 & 250.06 & 346 & 241.53 & $23,538.000$ & -0.758 & 0.488 \\
\hline & $\begin{array}{c}\text { All Age } \\
\text { Groups/Adult }\end{array}$ & 42 & 269.00 & 445 & 241.64 & 8295.000 & -1.505 & 0.132 \\
\hline \multirow{10}{*}{ 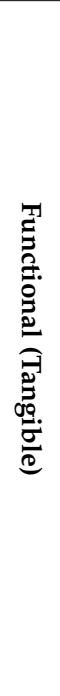 } & Attractions (seeing) & & & & & & & \\
\hline & $\begin{array}{l}\text { Architecture/Building } \\
\text { (Design) }\end{array}$ & 41 & 230.39 & 446 & 245.25 & 8585.000 & -0.808 & 0.419 \\
\hline & Watch Tower (view) & 27 & 224.70 & 460 & 245.13 & 5689.000 & -0.916 & 0.360 \\
\hline & $\begin{array}{c}\text { Demonstrative } \\
\text { Activities }\end{array}$ & 55 & 258.96 & 432 & 242.09 & $11,057.000$ & -1.046 & 0.296 \\
\hline & Other & 40 & 239.38 & 447 & 244.41 & 8755.000 & -0.271 & 0.786 \\
\hline & $\begin{array}{c}\text { Activities } \\
\text { (doing/experience) } \\
\text { Historic Adventure } \\
\text { Tour Participation }\end{array}$ & 342 & 267.30 & 145 & 189.06 & $16,828.000$ & -7.009 & 0.000 \\
\hline & $\begin{array}{l}\text { Interactive } \\
\text { Activities }\end{array}$ & 38 & 249.29 & 449 & 243.55 & 8330.000 & -0.301 & 0.763 \\
\hline & Self-Guided Tour & 39 & 238.10 & 448 & 244.50 & 8510.000 & -0.335 & 0.738 \\
\hline & $\begin{array}{c}\text { Amenity } \\
\text { Food and } \\
\text { Beverage/Restaurant }\end{array}$ & 42 & 260.20 & 445 & 242.47 & 8664.500 & -0.975 & 0.329 \\
\hline & $\begin{array}{c}\text { Additional Service } \\
\text { Amenity }\end{array}$ & 25 & 269.52 & 462 & 242.62 & 5137.000 & -1.163 & 0.245 \\
\hline \multirow{2}{*}{ 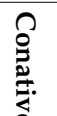 } & Behavior & 131 & 275.69 & 356 & 232.34 & $19,166.500$ & -3.766 & 0.000 \\
\hline & Attitude & 432 & 264.34 & 55 & 84.24 & 3093.000 & -11.168 & 0.000 \\
\hline
\end{tabular}

To evaluate the influence of all of the attributes on the Behavior and Attitude expressed in the reviews, a regression analysis was conducted. The result in Table 6 indicated that only Tour Guiding Excellence positively influenced Behaviors $(p<0.001)$. Visitors' intention to revisit and recommend the HTS to others was only influenced by the quality of the tour guide. For the TripAdvisor star rating and Attitude captured in visitors' reviews, the findings indicated the same result. Both were positively influenced by Tour Guiding Excellence, Historic/Authentic, Historic Adventure Tour Participation, Food and Beverage/Restaurant, and Additional Service Amenity $(p<0.05)$. This result indicates that visitors' rating of the HTS reflects their attitude toward the HTS; however, they may not rate the HTS based on their behavioral intention. 
Table 6. Influence of destination attribute on conation.

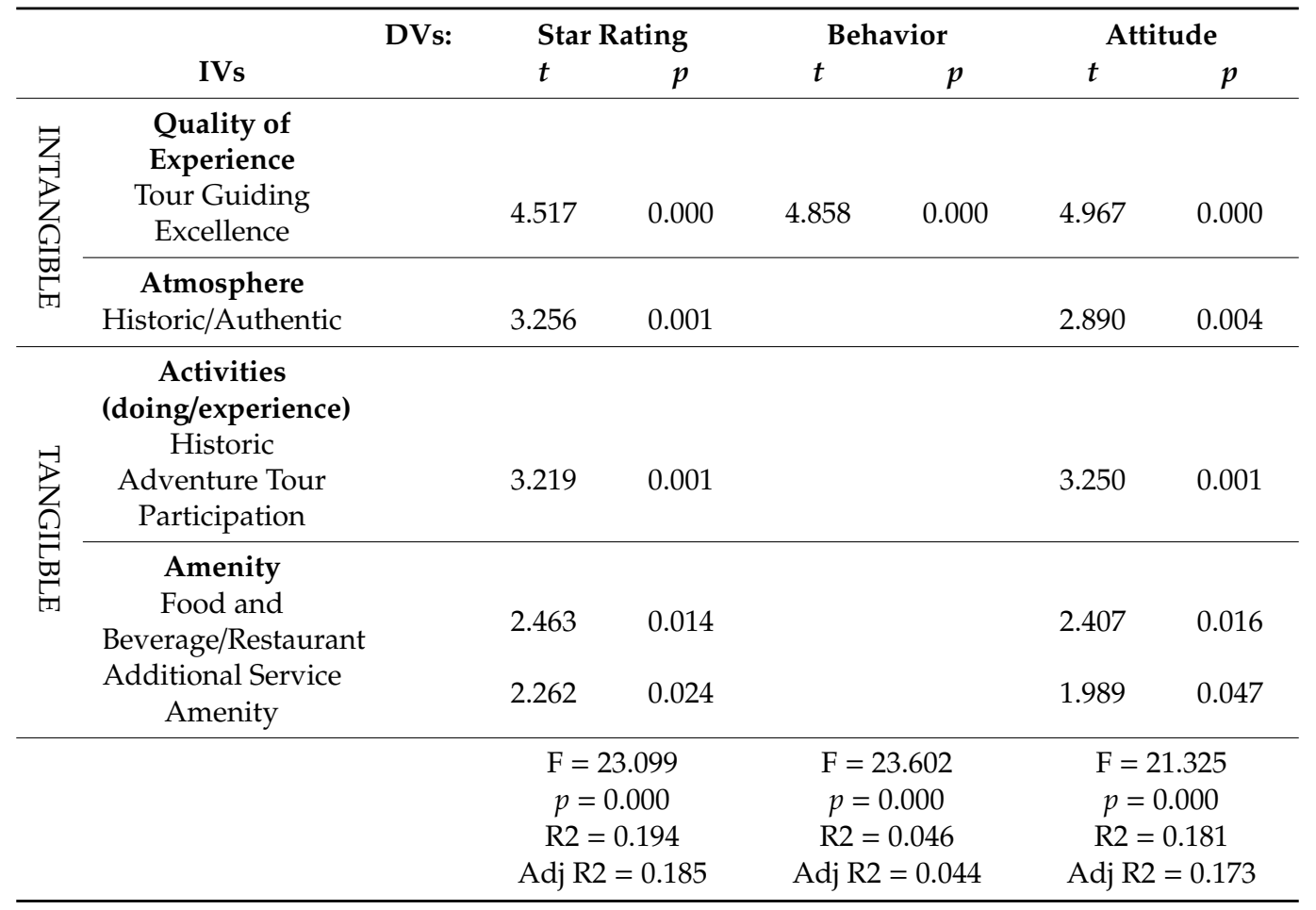

\section{Conclusions}

Destination attributes are a fundamental concept that underpins destination image, destination competitiveness, importance and performance, and many other tourism studies. As much as destination attributes have been used in tourism studies, the first step to many previous studies was to identify the measurement of destination attributes. There have been mainly two approaches to pre-identify the destination attributes as a measurement. One is to find a more generalizable set of destination attributes scale that is reliable and parsimonious [29]. The other is to adopt the destination attributes scale from previous studies and modify it to apply to the specific destination characteristics [17]. There is no consensus on which approach should be used. However, the generalizable scale serves as a guideline and modification is needed because no destination in the world is exactly the same as another destination. This study considered both aspects of destination attributes, by using Echtner and Ritchie's [29] attributes as a guideline and identifying the specific sets of attributes that capture the uniqueness of the destination characteristics.

This study also answers Meng et al.'s [17] question, "are there any other influential factors that should be included to give a more holistic picture of measuring tourist satisfaction?" (p.53). The study first identified destination attributes that are specific to the destination by observing tourists' real experiences, as presented in an online travel community. Through this observation, the findings indicated the salient destination attributes from the perspective of the tourist. Further, associations between the attributes and the visitors' satisfaction, attitudes, and behavioral intentions were found. In this destination context, in visitors' minds, attributes related to the tour program were found to be influential to their positive attitudes toward the destination and result in satisfaction. The quality of a tour guide as a storyteller and re-enactor were found to be the most important attributes, as the quality of tour guides was the most frequently mentioned attribute and was found to be influential to all three conative components. The findings of this study are meaningful because it revealed what is important to the visitors based on their real experiences in this destination. This viewpoint is supported by Litvin and Ling [34], as they stated that identifying the important destination attributes to a guest based on an understanding of their real experience is critical in destination marketing. 
The findings from this study contribute to the co-creation literature in tourism. Recent tourism studies applying the co-creation concept have advocated that tourists are a co-creator and that tourists' involvement can enhance products and services at a [66,88]. Prebensen et al. [88] argued that tourists travel to fulfill their needs and wants; and are likely to satisfy their needs and wants. This, therefore, results in positive experiences when their opinion is reflected in the creation process of tourism products and services. This study views tourists as active agents who can provide valuable and honest feedback about a destination, which can be used to improve the destination's offerings for potential tourists. Moreover, this study supports the co-creation studies that have indicated that online communities such as social media sites are a great tool for engaging consumers [66,89]. Further, Tussyadiah and Zach [90] and Oliveira and Panyik [66] argued that having to understand consumer generated content and include the knowledge gained by investigating the content in a destination's product and brand development is co-creation; and that this co-creation process can increase the capacity of tourism service providers in the destination.

The significant contribution of this is in providing managerial implications. This study was designed to find the destination attributes of a micro-scale tourism attraction that is important to tourists so that the attraction's management can identify which attributes should be enhanced or improved to provide a better experience for future visitors. By providing services and experiences that tourists can enjoy, tourism service providers can attract more tourists. The increased tourist demand can contribute to sustainable earnings from tourism that destination can expect continuous earning throughout the year rather than sporadic seasonal earning. These earnings can help destinations improve physical and social conditions within the host community [2]. For example, revenue earned through tourism can contribute to building community infrastructure and support educational and social programs. The study findings indicate that monitoring online communities can provide valuable information that managers can use in the strategic planning process. In the case of the study location, the attraction had thought of removing the guided tour program due to the financial resources put into the program to hire a qualified guide. However, the findings clearly revealed that the guided program and guided quality are the attributes that make the attraction valuable to visitors. While this study focused on a specific destination, this case was able to demonstrate to the destination service providers how a simple act of observing the tourists' online discussion can help them diagnose their current performance and manage the attraction effectively.

Author Contributions: Conceptualization, H.K. and Y.C.; Methodology, Y.C. and H.J.; Formal analysis, Y.C.; Investigation, Y.C. and A.S.; Data curation, Y.C.; Writing-original draft preparation, H.K. and A.S.; Writing-review and editing, A.S.; supervision, H.J.; project administration, H.K.; funding acquisition, H.K.

Funding: This work was supported by the BB21+ Project in 2019.

Conflicts of Interest: The authors declare no conflicts of interest.

\section{References}

1. Kim, H.; Stepchenkova, S.; Babalou, V. Branding destination co-creatively: A case study of tourists' involvement in the naming of a local attraction. Tour. Manag. Perspect. 2018, 28, 189-200. [CrossRef]

2. Cooper, C.; Hall, C.M. Contemporary Tourism: An International Approach, 3rd ed.; Goodfellow Publishers: Oxford, UK, 2018; ISBN 1911396773.

3. Weaver, D.B.; David, B. Sustainable Tourism: Theory and Practice; Elsevier Butterworth-Heinemann: Oxford, UK, 2007; ISBN 1136360484.

4. Choi, H.C.; Sirakaya, E. Sustainability indicators for managing community tourism. Tour. Manag. 2006, 27, 1274-1289. [CrossRef]

5. Stoddard, J.E.; Pollard, C.E.; Evans, M.R. The Triple Bottom Line: A Framework for Sustainable Tourism Development. Int. J. Hosp. Tour. Adm. 2012, 13, 233-258. [CrossRef]

6. Hammer, J.; Pivo, G. The Triple Bottom Line and Sustainable Economic Development Theory and Practice. Econ. Dev. Q. 2017, 31, 25-36. [CrossRef] 
7. Zeng, B. Cultural Centre, Destination Cultural Offer and Visitor Satisfaction. Sustainability 2017, 9, 1984. [CrossRef]

8. UNEP and UNWTO Making Tourism More Sustainable-A Guide for Policy Makers. Available online: https://sdt.unwto.org/content/about-us-5 (accessed on 14 July 2019).

9. World Tourism Organization. UNWTO Tourism Highlights. 2019. Available online: www.e-unwto.org/doi/ book/10.18111/9789284419876 (accessed on 22 August 2019).

10. Prebensen, N.K.; Woo, E.; Chen, J.S.; Uysal, M. Experience Quality in the Different Phases of a Tourist Vacation: A Case of Northern Norway. Tour. Anal. 2012, 17, 617-627. [CrossRef]

11. Tasci, A.D.A.; Gartner, W.C. Destination Image and Its Functional Relationships. J. Travel Res. 2007, 45, 413-425. [CrossRef]

12. Milman, A.; Pizam, A. The Role of Awareness and Familiarity with a Destination: The Central Florida Case. J. Travel Res. 1995, 33, 21-27. [CrossRef]

13. Coltman, M.M. Tourism Marketing; Van Nostrand Reinhold: New York, NY, USA, 1989.

14. Hunt, J.D. Image as a Factor in Tourism Development. J. Travel Res. 1975, 13, 1-7. [CrossRef]

15. Crompton, J.L. Motivations for pleasure vacation. Ann. Tour. Res. 1979, 6, 408-424. [CrossRef]

16. Pearce, P.L. Perceived changes in holiday destinations. Ann. Tour. Res. 1982, 9, 145-164. [CrossRef]

17. Meng, F.; Tepanon, Y.; Uysal, M. Measuring tourist satisfaction by attribute and motivation: The case of a nature-based resort. J. Vacat. Mark. 2008, 14, 41-56. [CrossRef]

18. Weaver, P.A.; McCleary, K.W.; Lapisto, L.; Damonte, L.T. The Relationship of Destination Selection Attributes to Psychological, Behavioral and Demographic Variables. J. Hosp. Leis. Mark. 1994, 2, 93-109. [CrossRef]

19. Enright, M.J.; Newton, J. Tourism destination competitiveness: A quantitative approach. Tour. Manag. 2004, 25, 777-788. [CrossRef]

20. Kozak, M. Measuring tourist satisfaction with muliple destination attributes. Tour. Anal. 2003, 7, $229-240$. [CrossRef]

21. Rodríguez-Díaz, M.; Rodríguez-Díaz, R.; Rodríguez-Voltes, A.; Rodríguez-Voltes, C.; Rodríguez-Díaz, M.; Rodríguez-Díaz, R.; Rodríguez-Voltes, A.C.; Rodríguez-Voltes, C.I. A Model of Market Positioning of Destinations Based on Online Customer Reviews of Lodgings. Sustainability 2017, 10, 78. [CrossRef]

22. Xu, Y.; Jin, W.; Lin, Z. Tourist post-visit attitude towards products associated with the destination country. J. Destin. Mark. Manag. 2018, 8, 179-184. [CrossRef]

23. Kim, H.; Stepchenkova, S. Understanding destination personality through visitors' experience: A cross-cultural perspective. J. Destin. Mark. Manag. 2017, 6, 416-425. [CrossRef]

24. Tapachai, N.; Waryszak, R. An Examination of the Role of Beneficial Image in Tourist Destination Selection. J. Travel Res. 2000, 39, 37-44. [CrossRef]

25. Banyai, M.; Glover, T.D. Evaluating Research Methods on Travel Blogs. J. Travel Res. 2012, 51, $267-277$. [CrossRef]

26. Konecnik, M.; Go, F. Tourism destination brand identity: The case of Slovenia. J. Brand Manag. 2008, 15, 177-189. [CrossRef]

27. Sigala, M.; Marinidis, D. E-Democracy and Web 2.0: A Framework Enabling DMOS to Engage Stakeholders in Collaborative Destination Management. Tour. Anal. 2012, 17, 105-120. [CrossRef]

28. Alvarez, M.D. Marketing of Turkey as a Tourism Destination. Anatolia 2010, 21, 123-138. [CrossRef]

29. Echtner, C.M.; Ritchie, J.R.B. The meaning and measurement of destination image. J. Tour. Stud. 2003, 14, 37-48.

30. Hernández-Lobato, L.; Solis-Radilla, M.M.; Moliner-Tena, M.A.; Sánchez-García, J. Tourism Destination Image, Satisfaction and Loyalty: A Study in Ixtapa-Zihuatanejo, Mexico. Tour. Geogr. 2006, 8, 343-358. [CrossRef]

31. Baloglu, S.; McCleary, K.W. A model of destination image formation. Ann. Tour. Res. 1999, $26,868-897$. [CrossRef]

32. Chon, K.S.; Weaver, P.A.; Kim, C.Y. Marketing Your Commmunity: Image Analysis in Norfolk. Cornell Hotel Restaur. Adm. Q. 1991, 31,31-37. [CrossRef]

33. Fakeye, P.C.; Crompton, J.L. Image differences between prospective, first-time, and repeat visitors to the Lower Rio Grande Valley. J. Travel Res. 1991, 30, 10-16. [CrossRef]

34. Litvin, S.W.; Ng Sok Ling, S. The destination attribute management model: An empirical application to Bintan, Indonesia. Tour. Manag. 2001, 22, 481-492. [CrossRef] 
35. Ritchie, J.R.B.; Crouch, G.I.; Geoffrey, I. The Competitive Destination: A Sustainable Tourism Perspective; CAB International: Oxford, UK, 2003; ISBN 184593010X.

36. San Martín, H.; Rodríguez del Bosque, I.A. Exploring the cognitive-affective nature of destination image and the role of psychological factors in its formation. Tour. Manag. 2008, 29, 263-277. [CrossRef]

37. Dwyer, L.; Mellor, R.; Livaic, Z.; Edwards, D.; Kim, C. Attribute of destination competitiveness: A factor analysis. Tour. Anal. 2004, 9, 91-101. [CrossRef]

38. Cha, S.; Mccleary, K.W.; Uysal, M. Travel Motivations of Japanese Overseas Travelers: A Factor-Cluster Segmentation Approach. J. Travel Res. 1995, 34, 33-39. [CrossRef]

39. Uysal, M.; Jurowski, C. Testing the push and pull factors. Ann. Tour. Res. 1994, 21, 844-846. [CrossRef]

40. Uysal, M.; Hagan, L.A.R. Motivation of Pleasure Travel and Tourism. In VNR's Encyclopedia of Hospitality and Tourism; Khan, M.A., Olsen, M.D., Var, T., Eds.; Van Nostrand Reinhold: New York, NY, USA, 1993; pp. 798-813. ISBN 0442003463.

41. Fluker, M.R.; Turner, L.W. Needs, Motivations, and Expectations of a Commercial Whitewater Rafting Experience. J. Travel Res. 2000, 38, 380-389. [CrossRef]

42. Prayag, G.; Hosany, S. When Middle East meets West: Understanding the motives and perceptions of young tourists from United Arab Emirates. Tour. Manag. 2014, 40, 35-45. [CrossRef]

43. Dann, G.M.S. Anomie, ego-enhancement and tourism. Ann. Tour. Res. 1977, 4, 184-194. [CrossRef]

44. Yoon, Y.; Uysal, M. An examination of the effects of motivation and satisfaction on destination loyalty: A structural model. Tour. Manag. 2005, 26, 45-56. [CrossRef]

45. Klenosky, D.B. The "Pull" of Tourism Destinations: A Means-End Investigation. J. Travel Res. 2002, 40, 396-403. [CrossRef]

46. Crouch, G.I. Destination Competitiveness: An Analysis of Determinant Attributes. J. Travel Res. 2011, 50, 27-45. [CrossRef]

47. Dwyer, L.; Cvelbar, L.K.; Mihalič, T.; Koman, M. Integrated Destination Competitiveness Model: Testing Its Validity and Data Accessibility. Tour. Anal. 2014, 19, 1-17. [CrossRef]

48. Dwyer, L.; Forsyth, P.; Rao, P. The price competitiveness of travel and tourism: A comparison of 19 destinations. Tour. Manag. 2000, 21, 9-22. [CrossRef]

49. Hassan, S.S. Determinants of Market Competitiveness in an Environmentally Sustainable Tourism Industry. J. Travel Res. 2000, 38, 239-245. [CrossRef]

50. Buhalis, D. Marketing the competitive destination of the future. Tour. Manag. 2000, 21, 97-116. [CrossRef]

51. Soteriou, E.C.; Roberts, C. The Strategic Planning Process in National Tourism Organizations. J. Travel Res. 1998, 37, 21-29. [CrossRef]

52. Chacko, H.E. Positioning a tourism destination to gain a competitive edge. Asia Pacific J. Tour. Res. 1996, 1, 69-75. [CrossRef]

53. Chon, K.S.; Mayer, K.J. Destination Competitiveness Models in Tourism and Their Application to Las Vegas. J. Tour. Syst. Qual. Manag. 1995, 1, 227-246.

54. Vengesayi, S. Determinants and Outcomes of Tourism Destination Competitiveness and Destination Attractiveness; Monash University: Melbourne, Australia, 2005.

55. Hudson, S.; Ritchie, B.; Timur, S. Measuring destination competitiveness: An empirical study of Canadian ski resorts. Tour. Hosp. Plan. Dev. 2004, 1, 79-94. [CrossRef]

56. Dwyer, L.; Kim, C. Destination Competitiveness: Determinants and Indicators. Curr. Issues Tour. 2003, 6, 369-414. [CrossRef]

57. Kozak, M.; Rimmington, M. Measuring tourist destination competitiveness: Conceptual considerations and empirical findings. Int. J. Hosp. Manag. 1999, 18, 273-283. [CrossRef]

58. Mazanec, J.A. Competition among European Tourist Cities: A Comparative Analysis with Multidimensional Scaling and Self-Organizing Maps. Tour. Econ. 1995, 1, 283-302. [CrossRef]

59. Azzopardi, E.; Nash, R. A critical evaluation of importance-performance analysis. Tour. Manag. 2013, 35, 222-233. [CrossRef]

60. Slack, N. The Importance-Performance Matrix as a Determinant of Improvement Priority. Int. J. Oper. Prod. Manag. 1994, 14, 59-75. [CrossRef]

61. Joppe, M.; Martin, D.W.; Waalen, J. Toronto's Image as a Destination: A Comparative Importance-Satisfaction Analysis by Origin of Visitor. J. Travel Res. 2001, 39, 252-260. [CrossRef] 
62. O'Leary, S.; Deegan, J. Ireland's Image as a Tourism Destination in France: Attribute Importance and Performance. J. Travel Res. 2005, 43, 247-256. [CrossRef]

63. Pike, S.; Ryan, C. Destination Positioning Analysis through a Comparison of Cognitive, Affective, and Conative Perceptions. J. Travel Res. 2004, 42, 333-342. [CrossRef]

64. Amaral, F.; Tiago, T.; Tiago, F. User-generated content: tourists' profiles on TripAdvisor. Int. J. Strateg. Innov. Mark. 2014, 01, 137-147. [CrossRef]

65. Werthner, H.; Ricci, F. E-Commerce and Tourism. Commun. ACM 2004, 42, 101-105. [CrossRef]

66. Oliveira, E.; Panyik, E. Content, context and co-creation: Digital challenges in destination branding with references to Portugal as a tourist destination. J. Vacat. Mark. 2015, 21, 53-74. [CrossRef]

67. Jenkins, O. Photography and travel brochures: The circle of representation. Tour. Geogr. 2003, 5, 305-328. [CrossRef]

68. Urry, J.; Larsen, J. The Tourist Gaze 3.0; SAGE: London, UK, 2011; ISBN 1446250024.

69. Crawshaw, C.; Urry, J.; Urry, J. Tourism and the photographic eye. In Touring Cultures: Transformations of Travel and Theory; Rojek, C., Urry, J., Eds.; Routledge: London, UK, 1997; pp. 186-205.

70. Stepchenkova, S.; Zhan, F. Visual destination images of Peru: Comparative content analysis of DMO and user-generated photography. Tour. Manag. 2013, 36, 590-601. [CrossRef]

71. Prahalad, C.K.; Ramaswamy, V. Co-creation experiences: The next practice in value creation. J. Interact. Mark. 2004, 18, 5-14. [CrossRef]

72. Vargo, S.L.; Lusch, R.F.; Lusch, R.F. Evolving to a New Dominant Logic for Marketing. In The Service-Dominant Logic of Marketing: Dialog, Debate, and Directions; Lusch, R.F., Vargo, S.L., Eds.; Routledge: London, UK, 2014; pp. 21-46.

73. Kourtit, K.; Nijkamp, P.; Romão, J.; Kourtit, K.; Nijkamp, P.; Romão, J. Cultural Heritage Appraisal by Visitors to Global Cities: The Use of Social Media and Urban Analytics in Urban Buzz Research. Sustainability 2019, 11, 3470. [CrossRef]

74. Lu, W.; Stepchenkova, S. Ecotourism experiences reported online: Classification of satisfaction attributes. Tour. Manag. 2012, 33, 702-712. [CrossRef]

75. Lavrakas, P.J. Respondent Fatigue. In Encyclopedia of Survey Research Methods; Lavrakas, P.J., Ed.; Sage Publications, Inc.: Thousand Oaks, CA, USA, 2008; p. 743.

76. Crotts, J.C.; Mason, P.R.; Davis, B. Measuring Guest Satisfaction and Competitive Position in the Hospitality and Tourism Industry. J. Travel Res. 2009, 48, 139-151. [CrossRef]

77. Banyai, M. Travel Blogs: A Reflection of Positioning Strategies? J. Hosp. Mark. Manag. 2012, 21, 421-439. [CrossRef]

78. National Park Service Architecture \& Construction - Castillo de San Marcos National Monument (U.S. National Park Service). Available online: https:/www.nps.gov/casa/learn/historyculture/construction.htm (accessed on 14 July 2019).

79. Banerjee, S.; Chua, A.Y.K. In search of patterns among travellers' hotel ratings in TripAdvisor. Tour. Manag. 2016, 53, 125-131. [CrossRef]

80. Yoo, K.H.; Gretzel, U. What Motivates Consumers to Write Online Travel Reviews? Inf. Technol. Tour. 2008, 10, 283-295. [CrossRef]

81. TripAdvisor TripAdvisor Network Effect and the Benefits of Total Engagement. Available online: https: //www.tripadvisor.com/TripAdvisorInsights/w828 (accessed on 16 June 2019).

82. Arsal, I.; Backman, S.; Baldwin, E. Influence of an Online Travel Community on Travel Decisions. In Information and Communication Technologies in Tourism 2008; Springer: Vienna, Austria, 2008; pp. 82-93.

83. Landis, J.R.; Koch, G.G. The Measurement of Observer Agreement for Categorical Data. Biometrics 1977, 33, 159. [CrossRef]

84. Li, X. (Robert); Stepchenkova, S. Chinese Outbound Tourists' Destination Image of America. J. Travel Res. 2012, 51, 250-266. [CrossRef]

85. Stepchenkova, S.; Kim, H.; Kirilenko, A. Cultural Differences in Pictorial Destination Images: Russia through the Camera Lenses of American and Korean Tourists. 2015. Available online: https://journals.sagepub.com/ doi/abs/10.1177/0047287514535849?journalCode=jtrb (accessed on 21 August 2019).

86. Hogg, R.V.; McKean, J.W.; Craig, A.T.; Allen, T. Introduction to Mathematical Statistics; Pearson: Upper Saddle River, NJ, USA, 2005; ISBN 9780321795434. 
87. Ritchey, F.J. The statistical imagination: Elementary Statistics for the Social Sciences, 2nd ed.; McGraw Hill: Boston, MA, USA, 2007; ISBN 9780072943047.

88. Prebensen, N.K.; Vitters $\varnothing$, J.; Dahl, T.I. Value Co-creation significance of tourist resources. Ann. Tour. Res. 2013, 42, 240-261. [CrossRef]

89. Hajli, N.; Shanmugam, M.; Papagiannidis, S.; Zahay, D.; Richard, M.O. Branding co-creation with members of online brand communities. J. Bus. Res. 2017, 70, 136-144. [CrossRef]

90. Tussyadiah, I.; Zach, F. Social Media Strategy and Capacity for Consumer Co-Creation Among Destination Marketing Organizations. In Information and Communication Technologies in Tourism 2013; Springer: Berlin/Heidelberg, Germany, 2013; pp. 242-253.

(C) 2019 by the authors. Licensee MDPI, Basel, Switzerland. This article is an open access article distributed under the terms and conditions of the Creative Commons Attribution (CC BY) license (http://creativecommons.org/licenses/by/4.0/). 